\title{
A Keynes-Robinson Controversy: A Methodological Matter
}

Peter V. Mini, (E-mail: pmini@bryant.edu), Bryant University

\begin{abstract}
This paper examines a minor methodological foray by Keynes: his 1941 reaction to what is now a well-known conclusion of price theory, the so-called "below-capacity theorem" first advanced by Joan Robinson's 1933 Economics of Imperfect Competition. By the graphical analysis that has now become universal, the theorem "proves" that any profit-maximizing firm faced with a downwardsloping demand curve will produce to the left of the average cost curve's lowest point, the difference between this lowest-cost output and the output determined by MC=MR being a measure of excess capacity. The paper will conclude that Keynes' denigration of the theorem is wholly due to his different cast of mind, to a methodology that preferred observation and history over deductive methods.
\end{abstract}

eynes' observations about the below-capacity theorem are the by-product of a paper submitted by Michael Kalecki to the Economics Journal in 1941 attempting to extend The General Theory beyond the short-run. Keynes' reaction to it was that it was "highly, almost delirious nonsense." He thought that there were many "latent and tacit" assumptions, a combination of which might well explain his conclusions. But were the assumptions realistic? Keynes suspected that the whole deductive method was "carried to ludicrous lengths," as, for instance, in the assumption that "all firms are always working below capacity," even when the economy is at full employment. ${ }^{1}$

Joan Robinson, to whom Keynes had appealed for an opinion of Kalecki's paper, rose in his defense. After attempting to clarify what he might have meant, she says, "As for under-capacity working - that is part of the usual bag of tricks of Imperfect Competition theory." 2 In his reply Keynes proclaimed himself "innocent enough to be bewildered by the idea" of firms always working below capacity. He suspected that the theorem was the result of "esoteric abracadabra," and that Kalecki used "artificial assumptions which have no possible relation to reality or any other merit except that they happen to lead up to a needed result."."

Mrs. Robinson protested at Keynes calling imperfect competition "an esoteric doctrine." After providing Keynes with the familiar diagram "proving" the theorem, she added, "It may be awful rot - as you have always suspected - but for better or worse it is in all the text books now." Keynes' subsequent letter ignored Mrs. Robinson's point about the popularity of the theorem, and explained that by "esoteric" he meant based on "a whole contraption of secret knowledge, atmosphere and assumptions, quite unknown to above a half a dozen readers in the Journal at the outside. ${ }^{4}$

Meanwhile, Kalecki had been hard at work improving his article and clarifying his assumptions. His labours were only too successful, as Keynes remarked that now his "complaint" was precisely the opposite of what had been at the beginning: the conclusions seemed to him "plain as a pikestaff"! Now that the assumptions had been flushed out in the open, Keynes could not see how "the" elaborate apparatus of the reference system [model?] leads to any conclusion which is not obvious from the start"! " Keynes knew that the conclusions of a system of strictly deductive logic are really its premises in other form: that "Socrates is mortal" is obvious from the premise "All men are mortal." "Does the article tell you anything you did not know before" when you set up the model? Keynes asks rhetorically.

The exchange, I think, illuminates Keynes' attitude toward the method of economics and of value theory-an addendum to his reaction, three years earlier, to Tinbergen's work. It is evident that J. Robinson's below-capacity 
theorem was new to Keynes...eight years after the appearance of The Economics of Imperfect Competition for which he had acted as referee for Macmillian! ${ }^{6}$ Keynes was baffled not because he did not understand it, but because he did not share what we may call the "consensual presuppositions" of the profession, which all derive from the premise of rational behavior under conditions of certainty. As I said in my Philosophy and Economics (1974), once the scaffolding of more or less "esoteric" premises, assumptions, and axioms has been around for a few years and proven useful, the scaffolding comes down and theorems will stand up on ideological and on pragmatic grounds and nobody will question them. (In The General Theory itself Keynes complained that he could not find any written and specific account of many classical theories, exactly because these theories really rested on unquestioned ideological, methodological and political presuppositions). Mrs. Robinson herself, by the way, accuses economists of blind acceptance of theories. When defending her below-capacity theorem against Keynes' allegations she says that, "Under perfect competition any firm which is working at all must be working bang up to capacity even in a deep slump. This is certainly more and not less ridiculous" than the below-capacity theorem. ${ }^{7}$ Keynes did not pick up on this "defense" to discredit all of value theory, but an unprejudiced mind may conclude that, between the two, these eminent revolutionaries in a few brief letters managed to cast doubt and ridicule on the whole vast area of the "economics of the firm"!

Incidentally, Keynes had encountered the below-capacity theorem not only in 1932, when he wrote to Macmillan about Mrs. Robinson's manuscript, but also in 1937, when Bertil Ohlin asked him why he had not made use of the theorem to strengthen his under-employment conclusion of The General Theory. Keynes found the reference to imperfect competition very perplexing: "I cannot see how on earth it comes in. Mrs. Robinson, I may mention, read my proofs [of The General Theory] without discovering any connection...[I]n general...I should have thought there were overwhelming statistics to prove the contrary...I have no clear idea what it is you are driving at."

Keynes' perplexity is due to the fact that he never entered into the point of view, the premises, the epistemology that produced the well-known mathematical functions of demand, supply, marginal revenues, or costs. The whole paraphernalia of value theory was "abracadabra" to him (like Tinbergen's work), for otherwise Mrs. Robinson's diagram, very intelligible to today's freshmen, would have proved the theorem. Today's freshmen (a few of whom later become economists) are led slowly, assumption by easy assumption, into supine acceptance of falling demand curves. They do not stop to reflect that such curves mean that the buyer and the seller know not only the present price-quantity combination but any such combinations, from a zero to a very high price. Students accept the clear separation of "data" from the independent variable, and the presumption of stability of the "data." They accept a mechanistic, impersonal, unidirectional cause and effect relation. If a student shows too much originality and introduces psychological, political, circular relationships - "irrationalities" - we know how to deal with him! Students accept the independence of demand and supply curves from each other. (Today they even accept the independence of aggregate demand and aggregate supply!) They accept the shape of the cost curves because they accept the relation between labor and the output of gasoline in an oil refinery as described by the short-run production function! It is all so overwhelming to them. But can one conceive Keynes being overwhelmed? In his reply to Ohlin he referred to the need for statistical evidence to prove the below-capacity theorem, which shows that his approach to economics was fundamentally factual and inductive.

The context within which Keynes' thought operated since 1915-the Treasury, the financial markets, the Macmillan Committee, etc — had no room for the "homily" but familiar concepts of value theory, all of them children of reason, all of them utterly a-political and un-psychological. Mrs. Robinson herself probably thought in separate, divided spheres: she implicitly saw The General Theory as dealing with life and her work with reason, which is why she did not call Keynes' attention to her own work in imperfect competition when reading the manuscript of The General Theory. Indeed, she called the below-capacity theorem "part of the usual bag of tricks of Imperfect Competition theory." Can anyone imagine Niels Bohr or Jonas Salk referring to their work as a bag of tricks? Would Keynes have referred to liquidity preference as a "trick"? When he confessed to being "still innocent enough to be bewildered" by the below-capacity theorem he meant to contrast "superficial" common-sense and observation to the "subtleties" of logical deduction from deceptively simple assumptions. Does common sense not tell us that any firm will strive to produce at full capacity if it possibly can? 
Keynes was not in sympathy with the logico-deductive method, and he said so often, for instance, in chapter 21 of The General Theory. Also, there is his 1934 observation that "Walras's theory and all others along those lines are little better than nonsense." 9 In 1923 he rejected a paper by Bertil Ohlin with the observation that "This amounts to nothing and should be refused." The paper dealt with the factor proportion theorem in international trade (also in all the textbooks now) which later would win Ohlin a Nobel Prize! And in 1928 Keynes also rejected a paper by Roy Harrod containing little less than the invention of the marginal cost curve. ${ }^{10}$ One can easily agree at least with the latter part of Hahn's judgement, that Keynes "had no real grasp of formal economic theory (and also disliked it)." 11

It is not sufficiently appreciated that Keynes did write on matters of what today we call micro-economics. He did study individual markets. In 1907, when he was at the India Office, he wrote on the market for jute. In 1923, on the market for U.K. entrepreneurial investments overseas. In 1926, on the coal and textile industries hit by the depression caused by a return to the pre-war parity with the dollar. In 1925 he attempted a classification of individual commodity price responses in a slump. From 1923 to 1930 he contributed annual analyses to the London and Cambridge Economic Service and other business publications, of the markets for American cotton, wool, jute, copper, lead, tin, zinc, rubber, sugar, coffee, tea, petroleum, nitrate and wheat. He returned to a study of these markets in the 1940s, advocating the setting up of international cartels of experts for each commodity, aiming at setting a "reasonable price" productive of stability and justice.

It is beyond the scope of this paper to review in detail Keynes' writings in these markets, especially since I have done so elsewhere. ${ }^{12}$ But some general conclusions may be drawn from them since they throw light on why Keynes was so baffled by the below-capacity theorem.

The first thing that strikes a modern reader is not only the total absence of diagrams in these analyses but even the absence of anything that can be called formal Marshallian economics. The terms demand and supply are used not as schedules relating prices to output but in the generic everyday sense of a statistical output purchased or sold. The analyses are immanent, time-bound, historical, and the statistics are in the tradition of his 1919 work on Germany's capacity to pay in The Economic Consequences of the Peace. They are "raw," "uncooked" and the source of the data are trade publication and private merchants' replies to questionnaires he sent out. And "supply" is sometimes a function of perceived "demand", and at other times of "inventory stocks."

Inventories have "an immense influence on the course of price changes," he says, to the point of being "the best index to impending instability of price" of a commodity. ${ }^{13}$

Being immanent and time bound, Keynes' analyses make no distinction between what we now call microeconomics and macro-economics. Keynes' macroeconomics was, of course, "monetary" not real, and the same can be said of his studies of pricing. He views commodity prices as being influenced by "monetary influences" in a major way. And the opposite relation is also true: crops that are produced only once a year often throw a great "strain on the credit and financial system," much more so than commodities like metals, that are produced continuously. Furthermore, price declines in one such commodities may "strain" the credit system "to the breaking point and conditions tending toward crisis tend to mature". ${ }^{14}$

Needless to say, the concept of equilibrium is totally absent from Keynes' market analyses. Indeed, this is the necessary result of seeing the world through the hazy lenses of uncertainty, ignorance, politics and assorted fears and passions. Referring to forward markets in commodities, for instance, which presumably exist to bring about "a harmony between short-period and long-period demand and supply" through the action of market "professionals", Keynes says that the presumption that professionals are "better informed than the producers and consumers themselves .... is rather a dubious proposition." ${ }^{15}$ This dismal judgement echoes, of course, that of The General Theory's chapter 21 about the professionals in the stock market.

We now understand why Keynes was bewildered by Joan Robinson's below-capacity theorem: he never got into the "intellectual grove," the deductive point of view, that led to it. He never thought in terms of functional relationships between hypothetical quantities and prices. Instead of proceeding from heaven to earth (deductive reasoning), he stayed consistently on earth and was content with a purely descriptive, value-laden method which, 
however, gave him the possibility of making policy recommendations. He used the terms demand and supply as statistical quantities, as facts fixed in time and space, that is, in the sense that merchants throughout the ages have used the terms.

Keynes' analyses of prices are historical, institutional and psychological — and the psychology he relied on was that of tentative, confused reactions taken in an environment of ignorance. Although he never gave sustained thought to matters of methodology, he probably imperfectly understood that "price theory" is a wholly idealistic construct using "eternal" and "universal" concepts and premises that have little to do with our world. He used the language and terminology of a gifted trade journal writer. He preferred realism and relevance to certainty of deductive results. The non-rationalistic elements that are present in his theory of output also appear in the microeconomics: uncertainty and ignorance — that is, history—pervade his analyses.

Much of our own micro-economics is informed by the question, "What is the nature of price?" This is a philosophical question, comparable to the question, "What is the nature of man?" It is this question that opened up the vast world of deer/beaver exchanges, indifference curves, revealed preferences, etc. leading to equilibrium. Keynes was not troubled by this question. Price existed and that was enough for him. His task was to explain the forcesimmanent in time and space - that would affect it.

\section{NOTES}

${ }^{1}$ Keynes, The Collected Writings (henceforth, CW) XII, 829 (4 February 1941)

${ }^{2}$ Ibid., 830 (4 February 1941).

${ }^{3}$ Ibid., 831 (12 February 1941)

${ }^{4}$ Ibid., 832 (18 February 1941)

5 Ibid., 833 (4 March 1941)

${ }^{6}$ Ibid., 866-8 (letter to Macmillan, 25 November 1932). In this letter Keynes states that his "confidence" in Mrs. Robinson's work is based on the fact that her manuscripts had been read by R. F. Kahn, in whose judgement Keynes indicated he had the greatest confidence! Perhaps an indication that he personally had little confidence in the diagrammatic method used by Mrs. Robinson.

${ }^{7}$ Keynes, CW XII, 832 (14 February 1941). Emphasis in the text.

${ }^{8} \mathrm{CW}$ XIV, 190, (29 April 1937).

9 Robert Skidelsky, John Maynard Keynes: the Economist as Savior, 1920-1937 (1992), 615.

${ }^{10}$ D. E. Moggridge, Maynard Keynes: An Economist's Biography (1992), 210.

${ }^{11}$ R. F. Hahn, Money and Inflation (1982), x-xi.

${ }^{12}$ P. V. Mini, Keynes on Markets: A Survey of Heretical Views, The American Journal of Economics and Sociology, Vol. 55 (January 1996), 99-111.

${ }^{13}$ Keynes, CW XII, 267 (from the London and Cambridge Economic Service, April 1923).

${ }_{14}^{14}$ Ibid., 257-9 (March 1923).

${ }_{15}^{15}$ Ibid., 260. 